\title{
Chemical characterization, texture and consumer acceptability of yogurts supplemented with quinoa flour
}

\author{
Carolina Antonela CURTI ${ }^{1 *}$, Paula Micaela VIDAL ${ }^{2}$, Ramiro Néstor CURTI ${ }^{3}$, Adriana Noemí RAMÓN²
}

\begin{abstract}
Quinoa can be used as a functional ingredient in food formulations. The aim of this study was to evaluate the effects on proximate composition, stability during storage, texture and consumer acceptability of yogurts supplemented with quinoa

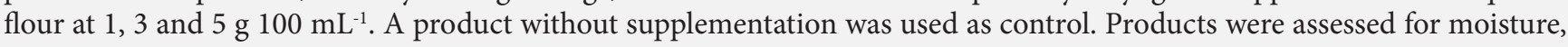
carbohydrates, proteins, fats, total dietary fibre (TDF), ashes and minerals. The $\mathrm{pH}$, acidity and syneresis of yogurts were measured after 1, 7, 14 and 21 days of storage and a Texture Profile Analysis (TPA) was carried out. Applying hedonic scale, 102 consumers analyzed the overall acceptability, color, texture, flavor and aroma of yogurts. Supplemented products showed significant higher protein, carbohydrate and fat contents. Hardness and adhesiveness showed a negative association whereas a positive one was found between springiness and cohesiveness. Yogurt is not necessarily the adequate matrix for hauling quinoa

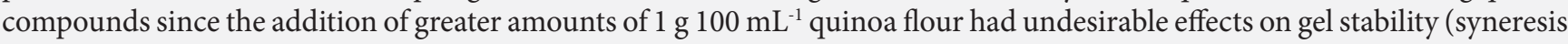
and increases in total acidity) and consumer acceptability.
\end{abstract}

Keywords: proximate composition; proteins; acidification during storage; sensory attributes.

Practical Application: The utilization of quinoa in yogurt formulations can enhance their nutritional value.

\section{Introduction}

Pseudocereals are healthy and nutritive foods which provide vectors for diversification and innovation (Collar et al., 2014). Quinoa, (Chenopodium quinoa Willd) a pseudocereal crop native to the Andes, has been recognized as a nutritious grain worldwide, due to both the relatively high nutritional value (compared to staple cereals) as a source of unsaturated fatty acids, vitamins, minerals and bioactive compounds, and the quality of its proteins as regards its essential amino acid content (Graf et al., 2015). Moreover, the recognition and diffusion of quinoa functional properties such as high water retention capacity, gelation and emulsification have allowed its increasing utilization in value-added products (Valcárcel-Yamani \& Lannes, 2012; Graf et al., 2015).

Numerous food and nutraceutical products have been developed from quinoa. Treated seeds have been used for flavoring or texturizing food products, flour as additives and fermented beverages were obtained by boiling, soaking and mixing quinoa with plant-derived extracts (Graf et al., 2015). However, only few studies have investigated the potential quinoa represents to supplement fermented dairy products (Casarotti et al., 2014).

Fermented milks, which are highly-consumed foods in the world and more nutritious compared to milk due to high contents of proteins, minerals and vitamins, have been traditionally used as matrices to deliver several functional components into human diet (Hashemi Gahruie et al., 2015). In general, the overall properties of yogurt, such as acidity level, the production of aroma compounds as well as the sensory profile (appearance, color and texture), are important traits which have a decisive role in consumer acceptance of products (Sfakianakis \& Tzia, 2014).

Several ingredients can be used in the formulation of yogurts. In this sense, inulin, fruit powders, vegetable oils, antioxidants, dietary fibre, minerals, probiotics, and vitamins have been successfully incorporated aiming to enhance their nutritional value and appeal to consumers (Sfakianakis \& Tzia, 2014). Changes in textural characteristics (cohesiveness, adhesiveness and firmness) were evinced and sensory attributes (flavor and aroma) were the limiting factors to consumer acceptability (Bertolino et al., 2014; Pelaes Vital et al., 2015; Perina et al., 2015; Pimentel et al., 2012; Sah et al., 2016). On the other hand, the addition of quinoa flour to yogurts contributed to postacidification during refrigerated storage (Casarotti et al., 2014).

Considering the possibility to supplement yogurts with quinoa flour, we hypothesized that this addition would not influence the physicochemical (chemical composition, texture, acidification and syneresis during storage) and sensory characteristics of final products. Hence, the aim of this study was to formulate

Received 11 Oct., 2016

Accepted 01 July, 2017

${ }^{1}$ Consejo Nacional de Investigaciones Científicas y Técnicas - CONICET, Instituto de Investigaciones para la Industria Química, Universidad Nacional de Salta - UNSa, Salta, Argentina

${ }^{2}$ Laboratorio de Alimentos, Facultad de Ciencias de la Salud, Universidad Nacional de Salta - UNSa, Salta, Argentina

${ }^{3}$ Consejo Nacional de Investigaciones Científicas y Técnicas - CONICET, Laboratorio de Investigaciones Botánicas - FCN, Universidad Nacional de Salta - UNSa, Sede

Regional Sur, Salta, Argentina

*Corresponding author: ccurti@unsa.edu.ar 
firm yogurts added with quinoa flour at different concentrations $\left(1,3\right.$ and $\left.5 \mathrm{~g} 100 \mathrm{~mL}^{-1}\right)$ and evaluate the effects on proximate composition, gel stability during storage, instrumental texture and consumer acceptability of final products.

\section{Materials and methods}

Quinoa seeds from Abralaite de Colanzulí, department of Iruya (3600 masl), Province of Salta, Argentina were manually classified and washed for $30 \mathrm{~min}$. with tap water to eliminate bitter taste and toxic saponins. Washed grains were dried at $55-60^{\circ} \mathrm{C}$ for $6 \mathrm{~h}$, packed in polyethylene bags and stored at room temperature until they were used in analysis and processing. Quinoa flour was obtained by grinding seeds in a coffee grinder and sieved into $250 \mu \mathrm{m}$.

\subsection{Formulation of firm yogurts}

Firm yogurts supplemented with quinoa flour were prepared as follows: $5 \mathrm{~g} 100 \mathrm{~mL}^{-1}$ sugar and different concentrations of quinoa

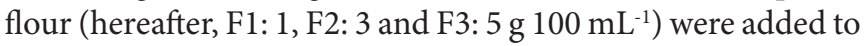
ultrapasteurized milk, mixed for 2 minutes, heated at $44^{\circ} \mathrm{C}$ and

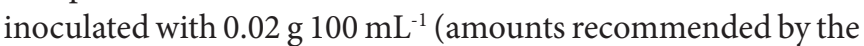
manufacturer) of commercial lyophilized culture of Streptococcus thermophilus and Lactobacillus acidophilus YF- L81 ${ }^{\circledR}$ from Chr. Hansen, Córdoba, Argentina. Vanilla $0.20 \mathrm{~mL} 100 \mathrm{~mL}^{-1}$ was added to formulations, packaged in sterile plastic cups and incubated in oven at $43-45^{\circ} \mathrm{C}$ until reaching $\mathrm{pH}$ 4.5. At the end of fermentation, yogurts were cooled to $5^{\circ} \mathrm{C}$ in an ice bath and stored for 21 days. Yogurt without supplementation was used as a control treatment.

\subsection{Proximate composition}

Quinoa flour was assessed according to the Association of Official Analytical Chemists (1995) methods and for carbohydrates (Fehling Causse Bonnans) proteins (micro-Kjeldhal), fats (Soxhlet), moisture and ashes by drying in an oven at $105^{\circ} \mathrm{C}$ and incinerating at $550{ }^{\circ} \mathrm{C}$, respectively. The factor used to transform percentage of nitrogen into percentage of protein was 6.25 (Stikic et al., 2012). Calcium and sodium were determined by atomic absorption spectroscopy whereas phosphorus by molecular absorption spectroscopy. All samples were analyzed considering three replicates. TDF content was calculated according to the Formulae 1:

$\% T D F=100-\left(\begin{array}{c}\% \text { moisture }+\% \text { carbohydrates }+ \\ \% \text { proteins }+\% \text { fats }+\% \text { ashes }\end{array}\right)$

The following variables were measured in firm yogurts: carbohydrates by difference; proteins (micro-Kjeldhal), fats (Gerber), moisture, ashes, Ca, Na, P (Association of Official Analytical Chemists, 1995). TDF was determined by enzymatic gravimetric method (Association of Official Analytical Chemists, 2003), only in sample with the best scores for all sensory attributes evaluated by consumers.

\subsection{Stability of yogurts during refrigerated storage}

The $\mathrm{pH}$ with a digital $\mathrm{pH}$-meter (Ludwing) and total acidity by titration (Association of Official Analytical Chemists, 1995) of yogurt samples were recorded at 1st, 7th, 14th, and 28th days during storage at $5{ }^{\circ} \mathrm{C}$. The spontaneous whey separation from undisturbed set yogurt was measured according to Amatayakul et al. (2006). Whey was collected from a yogurt cup at an angle of $45^{\circ}$ and results were expressed as percent of weight over the initial weight of yogurts.

\subsection{Instrumental texture of yogurts}

A TPA was carried out after one day of storage by employing a QTS-25 Brookfield Texture Analyzer. Yogurts in their original containers, were compressed using acrylic cylinder probe at a depth of $3 \mathrm{~mm}$, with a compression speed of $30 \mathrm{~mm} \mathrm{~min}^{-1}$, $5 \mathrm{~g}$ trigger point; target value and back-off distance of $8 \mathrm{~mm}$ and $10 \mathrm{~mm}$, respectively. Hardness (in $\mathrm{g}$ ), adhesiveness $\left(\mathrm{g} \mathrm{s}^{-1}\right.$ ) and springiness $(\mathrm{mm})$ and cohesiveness were calculated.

\subsection{Sensory evaluation}

Yogurts supplemented with quinoa flour were assed for acceptability by a panel of 102 healthy volunteers (without allergies or chronic diseases), frequent yogurt consumers aged between 18 and 49 years old (70\% female); who were recruited among students at the Faculty of Health Science, University of Salta, Argentina. After the selection, consumers were invited to taste yogurts without telling the particular ingredient which have been added. Thirty $\mathrm{mL}$ of each of the three experimental samples coded with a three-digit random number were presented simultaneously in disposable plastic cups. All samples were served at $5 \pm 1{ }^{\circ} \mathrm{C}$. Filtered tap water was also served to clean the mouth between samples. Panelists were asked to score their preference for overall acceptability, color, flavor, aroma and texture on a nine-point scale ranging from "like extremely" to "dislike extremely".

\subsection{Statistical analysis}

One-way analysis of variance with the Duncan's test for mean comparison was used to test differences among proximate composition of yogurt samples. A non-parametric Kruskal Wallis multiple range test was used to determine differences in scores assigned to sensory attributes on the hedonic-scale. Pearson's correlation coefficients and $t$ student test were used to calculate the magnitude and type of association between each pair of the instrumental texture parameters. Statistical analyses were conducted using statistical program Infostat (Di Rienzo et al., 2014).

\section{Results}

\subsection{Proximate composition}

The proximate composition of quinoa flour corresponded to

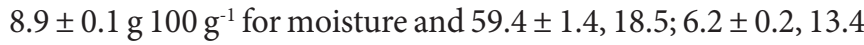

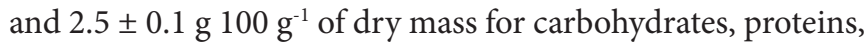
fats, TDF and ashes, respectively. $\mathrm{Ca}, \mathrm{Na}$ and $\mathrm{P}$ contents were 
$258 \pm 6.5,64$ and $123 \pm 1.9 \mathrm{mg} 100 \mathrm{~g}^{-1}$. It was possible to formulate firm yogurts supplemented with quinoa flour at 1,3 and $5 \mathrm{~g} 100 \mathrm{~mL}^{-1}$. According to results, significant differences were detected in carbohydrate, protein and fat contents between the control sample and supplemented yogurts (Table 1). A decrease in moisture content was observed as increasing the flour concentration although ashes (except from F3) and minerals (principally $\mathrm{Na}$ and $\mathrm{P}$ ) were not significantly different between samples (Table 1). The lowest calcium content was found in F3. Certainly, the $\mathrm{Ca} / \mathrm{P}$ ratio corresponded to 2:1 in supplemented yogurts and 3:1 in the control sample. TDF content was determined in F1 only and a value of $1.01 \%$ was found.

\subsection{Stability of yogurts during refrigerated storage}

A higher increase in total acidity values were observed in samples with greater amounts of quinoa flour (F2 and F3) compared to control and yogurt supplemented with $1 \mathrm{~g} 100 \mathrm{~mL}^{-1}$ (Figure 1A). The $\mathrm{pH}$ values of all products dropped during storage (Figure 1B) and the largest decrease was observed in F2 as a consequence of the increase in total acidity (Figure 1A). Syneresis was noticed in yogurts supplemented with 3 and $5 \mathrm{~g} 100 \mathrm{~mL}^{-1}$ quinoa flour and percentages of whey separation corresponded to 1.89 and $0.43 \%$ at $14 \mathrm{~d}$ and $2.67 \pm 0.01$ and $0.66 \pm 0.01 \%$ at $21 \mathrm{~d}$ of storage respectively.

\subsection{Instrumental texture of yogurts}

Of the 15 correlation coefficients evaluated, only two showed significant associations. Hardness and adhesiveness showed a negative association $(r=-0.79 ; P=0.02)$, whereas a positive one was found between springiness and cohesiveness $(r=0.72 ; P=0.04)$.
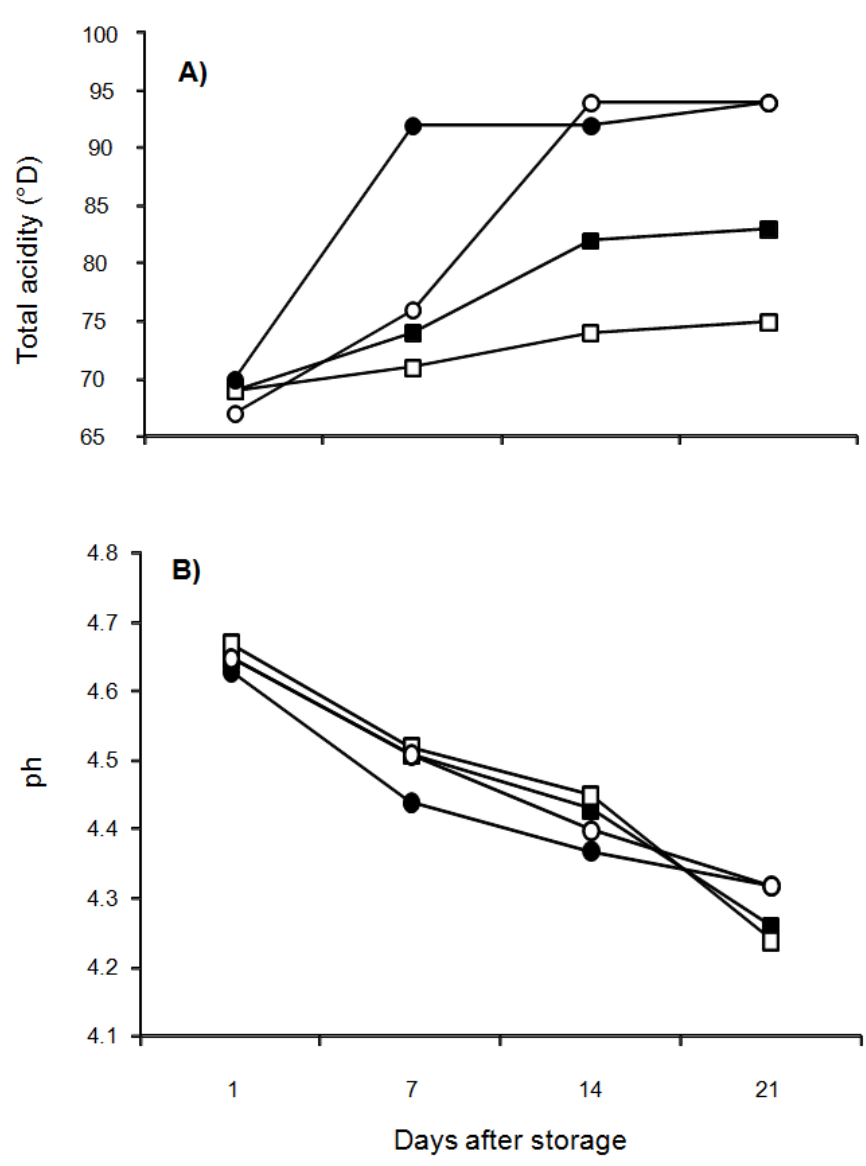

Figure 1. (A) Total acidity values expressed in Dornic degree and (B) $\mathrm{pH}$ values of control and supplemented yogurts. Values under the $x$-axis indicate the date of refrigerated storage. Control treatment

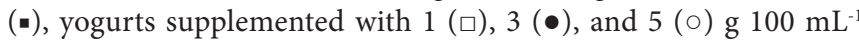
quinoa flour.

Table 1. Proximate composition of control and yogurts supplemented with quinoa flour. Moisture, carbohydrates, proteins, fats and ashes are expressed in $100 \mathrm{~mL}^{-1}$, whereas $\mathrm{Ca}, \mathrm{Na}$ and $\mathrm{P}$ in $\mathrm{mg} 100 \mathrm{~mL}^{-1}$.

\begin{tabular}{|c|c|c|c|c|}
\hline \multirow{2}{*}{ Traits } & \multicolumn{4}{|c|}{ Yogurts } \\
\hline & Control & $\mathrm{F} 1\left(1 \mathrm{~g} 100 \mathrm{~mL}^{-1}\right)$ & $\mathrm{F} 2\left(3 \mathrm{~g} 100 \mathrm{~mL}^{-1}\right)$ & $\mathrm{F} 3\left(5 \mathrm{~g} 100 \mathrm{~mL}^{-1}\right)$ \\
\hline Moisture & $82.6 \pm 0.1^{\mathrm{a}}$ & $79.5 \pm 0.62^{\mathrm{b}}$ & $78.5 \pm 0.5^{c}$ & $77.4 \pm 0.2^{\mathrm{d}}$ \\
\hline Carbohydrates & $7.6 \pm 0.1^{\mathrm{b}}$ & $9.1 \pm 0.58^{\mathrm{a}}$ & $9.5 \pm 0.7^{\mathrm{a}}$ & $9.5 \pm 0.1^{\mathrm{a}}$ \\
\hline Fats & $3.2 \pm 0.05^{\mathrm{a}}$ & $3.8 \pm 0.02^{\mathrm{b}}$ & $4.1 \pm 0.1^{\mathrm{c}}$ & $4.5 \pm 0.05^{\mathrm{d}}$ \\
\hline Ashes & $0.7 \pm 0.01^{\mathrm{a}}$ & $0.81 \pm 0.01^{\mathrm{a}}$ & $0.8 \pm 0.01^{\mathrm{a}}$ & $1.4 \pm 0.05^{\mathrm{b}}$ \\
\hline $\mathrm{P}$ & $58 \pm 0.9^{a}$ & $73 \pm 3.6^{a}$ & $72 \pm 2.4^{\mathrm{a}}$ & $74 \pm 1.7^{\mathrm{a}}$ \\
\hline
\end{tabular}

${ }^{\mathrm{a}-\mathrm{d}}$ Means in the same column followed by a different letter represent significant differences $(p<0.05)$.

Table 2. Consumer acceptability mean scores for sensory attributes evaluated in supplemented products.

\begin{tabular}{cccccc}
\hline Attributes & Overall acceptability & Color & Texture & Flavor & Aroma \\
\hline F1 & $7.6^{\mathrm{b}}$ & $7.5^{\mathrm{b}}$ & $7.5^{\mathrm{b}}$ & $7.5^{\mathrm{b}}$ & $7.4^{\mathrm{b}}$ \\
F2 & $6.1^{\mathrm{a}}$ & $6.6^{\mathrm{a}}$ & $6.9^{\mathrm{a}}$ & $6.9^{\mathrm{a}}$ & $5.8^{\mathrm{a}}$ \\
F3 & $5.9^{\mathrm{a}}$ & $6.5^{\mathrm{a}}$ & $6.6^{\mathrm{a}}$ & $6.6^{\mathrm{a}}$ & $5.5^{\mathrm{a}}$ \\
\hline
\end{tabular}

(F1, F2, F3) Yogurts supplemented with 1,3,5 g $100 \mathrm{~mL}^{-1}$ quinoa flour. ${ }^{\mathrm{a}, \mathrm{b}}$ Means in the same column followed by a different letter represent significant differences between samples $(p<0.05)$. 


\subsection{Sensory evaluation}

Regarding the sensory evaluation, F1 showed the best scores for all sensory attributes and significantly differed from F2 and F3 (Table 2). However, no significant differences were observed among F2 and F3 (Table 2). The mean score for overall acceptability in F1 was 7.6 which corresponds to "like the product moderately".

\section{Discussion}

According to results of the present study, the proximate composition of quinoa flour did not vary when compared to unprocessed seeds in regards with their nutritional composition (see Vidueiros et al., 2015). Consequently, quinoa flour could be considered as an alternative ingredient in food formulations for people affected by a chronic celiac disease since it may contain very little or no prolaminas content.

Certainly, quinoa seeds can provide vectors for food diversification and innovation since products with satisfactory nutritional qualities were obtained. The results showed that proximate composition of firm yogurts effectively modified after the addition of flour as higher carbohydrates, proteins and fats were exhibited. In this sense, an increase in the fat content could carry some of beneficial components (polyunsaturated fatty acids) which can play a significant role in the prevention of several chronic diseases (Lorente-Cebrián et al., 2013; Yates et al., 2014). A different behavior was noticed when quinoa and hazelnuts were added to fermented products, since a decrease in the above components was reported (Bertolino et al., 2014; Bianchi et al., 2015). In this study, the superiority of quinoa as a functional ingredient to enhance the nutritional value of yogurts has been elucidated.

The $\mathrm{pH}$ reduction and increases in total acidity of supplemented yogurts during storage could be possibly explained due to the higher consumption of residual lactose by the lactic acid bacteria. Casarotti et al. (2014) arrived to similar results in fermented milks added with 2 and $3 \mathrm{~g} 100 \mathrm{~mL}^{-1}$ quinoa flour. Thus, the shelf life of yogurts can reduce considerably after the addition of quinoa flour and this fact could significantly impact in the subsequent consumer acceptability of products.

Whey expulsion exhibited in yogurts supplemented with greater amounts of quinoa flour (F2 and F3) can be explained due to the loss of yogurt gel ability to entrap the water phase and can adversely affect the consumer acceptability (Purwandari et al., 2007). In this regard, changes in gel stability after the addition of flour suggest that yogurt is not necessarily the adequate matrix to deliver quinoa compounds.

According to results, the higher hardness values could be interpreted as a greater rearrangement of protein particles in the gel network. The cohesiveness (greater strength of internal bonds) together with springiness (the ability to recover its initial condition after applying a deformation) may indicate a large number of broken casein-casein linkages during stress application (Sandoval-Castilla et al., 2004). Hence, the cohesiveness and hardness values found in products with higher amounts of quinoa flour indicate that the utilization of this ingredient is not beneficial when textural properties have to be taken in account.

Regarding the sensory evaluation, the color of yogurts with higher concentrations of quinoa flour (F2 and F3) could have played a significant role in the later acceptability of aroma and flavor. In addition, F1 was perceived as having significantly more desirable flavor and aroma which could be attributed because consumers are not familiarized with the taste of quinoa. The results agreed well with Bianchi et al. (2015) who also found that the higher the proportion of quinoa in a product the lower the flavor acceptance. It is relevant to point out that the addition of quinoa flour effectively adjusted the sensory perception. The global impression is a complex term comprising the combination of different sensory perceptions. In this sense, consumer rejection of any of the sensory characteristics could negatively influence the overall perception of yogurts.

\section{Conclusions}

It was possible to formulate firm yogurts with quinoa flour. Although nutritional composition could be enhanced, the addition of quinoa flour had undesirable effects on texture. The overall acceptability decreases when increasing the flour concentration in a product. Hence, yogurt is not necessarily the adequate matrix for hauling quinoa compounds since the addition can adversely impact in the stability of gel during storage as syneresis and increases in total acidity were evinced.

\section{References}

Amatayakul, T., Halmos, A. L., Sherkat, F., \& Shah, N. P. (2006). Physical characteristics of yoghurts made using exopolysaccharideproducing starter cultures and varying casein to whey protein ratios. International Dairy Journal, 16(1), 40-51. http://dx.doi.org/10.1016/j. idairyj.2005.01.004.

Association of Official Analytical Chemists - AOAC. (1995). Official methods of analysis of the Association of Official Analytical Chemists (16th ed.). Arlington: Association of Analytical Communities.

Association of Official Analytical Chemists - AOAC. (2003). Official methods of analysis of the Association of Official Analytical Chemists (17th ed.). Gaithersburg: Association of Analytical Communities.

Bertolino, M., Belviso, S., Dal Bello, B., Ghirardello, D., Giordano, M., Rolle, L., Gerbi, V., \& Zeppa, G. (2014). Influence of the addition of different hazelnut skins on the physicochemical, antioxidant, polyphenol and sensory properties ofyogurt. Lebensmittel-Wissenschaft + Technologie, 63(2), 1145-1154. http://dx.doi.org/10.1016/j. lwt.2015.03.113.

Bianchi, F., Rossi, E., Gomes, R., \& Sivieri, K. (2015). Potentially synbiotic fermented beverage with aqueous extracts of quinoa (Chenopodium quinoa Willd) and soy. Food Science \& Technology International, 21(6), 403-415. PMid:24958776. http://dx.doi. org/10.1177/1082013214540672.

Casarotti, S. N., Carneiro, B. M., \& Penna, A. L. B. (2014). Evaluation of the effect of supplementing fermented milk with quinoa flour on probiotic activity. Journal of Dairy Science, 97(10), 6027-6035. PMid:25087036. http://dx.doi.org/10.3168/jds.2014-8197.

Collar, C., Jiménez, T., Conte, P., \& Fadda, C. (2014). Impact of ancient cereals, pseudocereals and legumes on starch hydrolysis and antiradical activity of technologically viable blended breads. 
Carbohydrate Polymers, 113, 149-158. PMid:25256469. http://dx.doi. org/10.1016/j.carbpol.2014.07.020.

Di Rienzo, J. A., Casanoves, F., Balzarini, M. G., Gonzalez, L., Tablada, M., \& Robledo, Y. C. (2014). InfoStat. Argentina: Grupo InfoStat. Retrieved from http://www.infostat.com.ar

Graf, B. L., Rojas-Silva, P., Rojo, L. E., Delatorre-Herrera, J., Baldeón, M. E., \& Raskin, I. (2015). Innovations in Health Value and Functional Food Development of Quinoa (Chenopodium quinoa Willd.). Comprehensive Reviews in Food Science and Food Safety, 14(4), 431445. PMid:27453695. http://dx.doi.org/10.1111/1541-4337.12135.

Hashemi Gahruie, H., Eskandari, M. H., Mesbahi, G., \& Hanifpour, M. A. (2015). Scientific and technical aspects of yogurt fortification: a review. Food Science and Human Wellness, 4(1), 1-8. http://dx.doi. org/10.1016/j.fshw.2015.03.002.

Lorente-Cebrián, S., Costa, A. G. V., Navas-Carretero, S., Zabala, M., Martínez, J. A., \& Moreno-Aliaga, M. J. (2013). Role of omega-3 fatty acids in obesity, metabolic syndrome, and cardiovascular diseases: a review of the evidence. Journal of Physiology and Biochemistry, 69(3), 633-651. PMid:23794360. http://dx.doi.org/10.1007/s13105013-0265-4.

Pelaes Vital, A. C., Goto, P. A., Hanai, L. N., Gomes-da-Costa, S. M., de Abreu Filho, B. A., Nakamura, C. V., \& Matumoto-Pintro, P. T. (2015). Microbiological, functional and rheological properties of low fat yogurt supplemented with Pleurotus ostreatus aqueous extract. Lebensmittel-Wissenschaft + Technologie, 64(2), 1028-1035. http:// dx.doi.org/10.1016/j.lwt.2015.07.003.

Perina, N. P., Granato, D., Hirota, C., Cruz, A. G., Bogsan, C. S. B., \& Oliveira, M. N. (2015). Effect of vegetal-oil emulsion and passion fruit peel-powder on sensory acceptance of functional yogurt. Food Research International, 70, 134-141. http://dx.doi.org/10.1016/j. foodres.2015.01.014.

Pimentel, T. C., Garcia, S., \& Prudêncio, S. H. (2012). Effect of longchain inulin on the texture profile and survival of Lactobacillus paracasei ssp. paracasei in set yoghurts during refrigerated storage. International Journal of Dairy Technology, 65(1), 104-110. http:// dx.doi.org/10.1111/j.1471-0307.2011.00739.x.

Purwandari, U., Shah, N. P., \& Vasiljevic, T. (2007). Effects of exopolysaccharide-producing strains of Streptococcus thermophilus on technological and rheological properties of set-type yoghurt. International Dairy Journal, 17(11), 1344-1352. http://dx.doi. org/10.1016/j.idairyj.2007.01.018.

Sah, B. N. P., Vasiljevic, T., McKechnie, S., \& Donkor, O. N. (2016). Physicochemical, textural and rheological properties of probiotic yogurt fortified with fibre-rich pineapple peel powder during refrigerated storage. Lebensmittel-Wissenschaft + Technologie, 65, 978-986. http://dx.doi.org/10.1016/j.lwt.2015.09.027.

Sandoval-Castilla, O., Lobato-Calleros, C., Aguirre-Mandujano, E., \& Vernon-Carter, E. J. (2004). Microstructure and texture of yogurt as influenced by fat replacers. International Dairy Journal, 14(2), 151-159. http://dx.doi.org/10.1016/S0958-6946(03)00166-3.

Sfakianakis, P., \& Tzia, C. (2014). Conventional and innovative processing of milk for yogurt manufacture; development of texture and flavor: a review. Foods, 3(1), 176-193. PMid:28234312. http:// dx.doi.org/10.3390/foods3010176.

Stikic, R., Glamoclija, D., Demin, M., Vucelic-Radovic, B., Jovanovic, Z., Milojkovic-Opsenica, D., Jacobsen, S.-E., \& Milovanovic, M. (2012). Agronomical and nutritional evaluation of quinoa seeds (Chenopodium quinoa Willd.) as an ingredient in bread formulations. Journal of Cereal Science, 55(2), 132-138. http://dx.doi.org/10.1016/j. jcs.2011.10.010.

Valcárcel-Yamani, B., \& Lannes, S. C. da S. (2012). Applications of Quinoa (Chenopodium Quinoa Willd. ) and Amaranth (Amaranthus Spp.) and Their Influence in the Nutritional Value of Cereal Based Foods. Food and Public Health, 2(6), 265-275. http://dx.doi.org/10.5923/j. fph.20120206.12.

Vidueiros, S. M., Curti, R. N., Dyner, L. M., Binaghi, M. J., Peterson, G., Bertero, H. D., \& Pallaro, A. N. (2015). Diversity and interrelationships in nutritional traits in cultivated quinoa (Chenopodium quinoa Willd.) from Northwest Argentina. Journal of Cereal Science, 62, 87-93. http://dx.doi.org/10.1016/j.jcs.2015.01.001.

Yates, C. A., Calder, P. C., \& Rainger, C. E. (2014). Pharmacology and therapeutics of omega-3 polyunsaturated fatty acids in chronic inflammatory disease. Pharmacology \& Therapeutics, 141(3), 272-282. PMid:24201219. http://dx.doi.org/10.1016/j.pharmthera.2013.10.010. 